Article

\title{
Smallholder Decision-Making on Sawlog Production: The Case of Acacia Plantation Owners in Central Vietnam
}

\author{
Eliza Zhunusova ${ }^{1, *}$, Le Thi Hoa Sen ${ }^{2}{ }^{\mathbb{D}}$, Jobst-Michael Schröder ${ }^{1}$, Stefan Ziegler ${ }^{3}$, \\ Matthias Dieter ${ }^{1}$ and Sven Günter ${ }^{1}$ \\ 1 Thünen Institute of International Forestry and Forest Economics, Leuschnerstr. 91, 21031 Hamburg, \\ Germany; jobst.schroeder@thuenen.de (J.-M.S.); matthias.dieter@thuenen.de (M.D.); \\ sven.guenter@thuenen.de (S.G.) \\ 2 Hue University of Agriculture and Forestry, Hue University, 102 Phung Hung, Hue city, Vietnam; \\ sen.lethihoa@huaf.edu.vn \\ 3 World Wide Fund for Nature (WWF) Germany, Reinhardtstr. 18, 10117 Berlin, Germany; \\ stefan.ziegler@wwf.de \\ * Correspondence: eliza.zhunusova@thuenen.de
}

Received: 2 October 2019; Accepted: 31 October 2019; Published: 2 November 2019

\begin{abstract}
Background and objectives: Smallholder households with a plot size of 1-5 ha manage nearly half of Vietnam's acacia plantations. They mostly harvest acacia timber after short rotation periods (5-6 years) producing woodchips with relatively low financial returns compared to potential profits from sawlog production through long rotation periods. The domestic wood production cannot yet meet the needs of the booming furniture industry for raw materials. This paper investigates factors that influence the adoption of long-rotation periods for sawlog production by small-scale plantation owners. Materials and methods: The impact of farmer and farm characteristics and the characteristics of the external environment on the probability to adopt long rotation periods is analyzed. The data were collected through focus group discussions (FGD) and a household survey to capture the wider socio-economic situation of small-scale plantation owners in central Vietnam. Findings: Results from FGDs and probit regressions show that factors that potentially constrain small-scale plantation owners from the production of sawlogs can be grouped into four themes: (1) small and fragmented land holdings, (2) high risks related to natural disasters and other biotic and abiotic hazards, (3) high production and monitoring costs, and (4) lack of knowledge and experience in plantation management. Conclusions: Potential policy approaches to promote the adoption of long rotation periods should include a package of measures that simultaneously address the constraints of smallholders and the various risks that they face.
\end{abstract}

Keywords: Acacia mangium; short rotation period; long rotation period; smallholder constraints

\section{Introduction}

Vietnam is one of the few tropical countries that has experienced a shift from net deforestation to net reforestation over the last three decades with a rapid expansion of the forest cover from $28.3 \%$ in 1990 up to $40.8 \%$ in 2015 , largely due to expansion of forest plantations [1,2]. Several factors contributed to this forest transition, including efforts of the government to decentralize agricultural production, devolution of forestry land to households, and the overall transformation of the economic system from a centrally planned to a market-oriented system [3]. Two main instruments were used to increase the forest area: safeguarding remaining natural forests via the expansion of protected areas and the adoption of national "5 Million Hectare Reforestation Program" (5MHRP) in 1998 to reforest 5 M ha 
of degraded and barren lands [4]. While the area of the remaining primary forest is less than $1 \%$ of the total land area, area under tree plantations expanded from $1 \mathrm{M}$ ha to $3.2 \mathrm{M}$ ha during 1990-2015, making up $10 \%$ of the national land area [1]. Vietnam also plays an important role in international trade in tropical timber, and is the world's largest exporter of tropical wooden furniture, but the domestic wood production cannot yet meet the needs of the booming furniture industry for raw materials [5].

One of the national government's goals within the framework of the 5MHRP was to improve the provision of raw materials for wood-based industries and income for rural households through the establishment and expansion of forest plantations. With the passing of Decree 163 in 1999, individuals and households were entitled to receive a so-called Red Book for the forestland allocated to them, which is a land use certificate valid for a period of 50 years (Decree No. 163/1999/ND-CP). Policy measures to promote forest plantations include access to preferential loans associated to reforestation programs, land fee exemptions, and direct payments made within the 5MHRP, whereas households that invest in long-term rotations (up to 30 years) of tree plantations can receive grants of 2 million VND (US\$ 85.7) per ha (Decisions No. 100/2007/QD-TTg and No.38720167QD-TTg of the Prime Minister). Several donor-funded and government initiatives have been focusing on promoting long rotation periods among the smallholder forest owners in Vietnam, including projects from the German Development Cooperation (GIZ), World Bank, and World Wide Fund for Nature (WWF).

Acacia mangium Willd. and Acacia auriculiformis A. Cunn. ex Benth. (and the clonal hybrid of both) are the main acacia species used for forest plantations in Vietnam, preferred for their nitrogen-fixing ability and fast growth even on poor soils, while the species also exhibit a potential for use in agroforestry systems [6]. Forest growers with varying access to capital, technology and skills are involved in acacia plantations [7]. Small-scale forest owners with land holdings under 5 ha altogether manage $46 \%$ of the area under acacia plantations. Other growers include state management boards $(17 \%)$, state companies $(15 \%)$, people's committees (12\%), private companies $(4 \%)$ and other growers [8].

Two main uses of acacia plantations are pulpwood for woodchip and sawn timber for furniture production. The majority of small-scale forest owners sell their output for woodchip after a short rotation period of 4 to 6 years [9]. Despite the expansion of forest plantations, the domestic furniture industry depends heavily on the imports of sawn wood: in 2015, Vietnam imported US\$ 1.6 billion worth of raw wood materials, mainly from Laos, the USA, Cambodia, China and Malaysia [10]. Wood processing companies in Vietnam sourced approximately $50 \% 60 \%$ of raw materials from imports as of 2015 [10].

Acacia logs with diameter $15 \mathrm{~cm}$ or more and free of large knots can be used for sawing and veneering and can be sold for higher prices than woodchip [7]. In order to produce sawlogs, rotation periods have to be extended and additional investments may be needed. Long rotation periods for the production of sawlogs could bring higher monetary returns, but evidence remains limited. Using a case study of a State Forestry Company in Vietnam, Maraseni et al. showed that the Net Present Value (NPV) for a 10-year rotation period can be 4 times as higher as that from a 5-year rotation [11]. One can expect however, that prices for woodchip and sawlogs vary across regions in Vietnam, and the situation of small-scale plantation owners can be different than that of a State Forest Company. Small-scale forest owners are often poor and need early returns from acacia plantations with minimum risk, which makes the expansion to long rotations for sawlog production difficult to achieve [12].

Despite the higher potential profitability of sawlog plantations, the uptake by smallholder farmers of this practice has been slow. This paper investigates factors that influence smallholder adoption of long-rotation sawlog production in Vietnam. To the best of our knowledge, no empirical study has yet investigated the factors that influence production of sawlogs from acacia plantations by small-scale forest owners in Vietnam. Qualitative data from focus group discussions (FGDs) are combined with regression analysis to provide a broader understanding of plantation owners' decision-making with regard to rotation length and the production of sawlogs versus woodchip. The findings of this study can serve as a useful background for future policy making related to small-scale forest management in Vietnam. 


\section{Materials and Methods}

\subsection{Data Collection and the Study Area}

Data were collected through focus group discussions and a household survey conducted during November to December 2017. This study focuses on the three provinces of Quang Nam, Quang Tri, and Thua Thien Hue in central Vietnam, where in total 18 communes (A commune is a third-tier administrative subdivision in Vietnam following a province and a district.) were selected (Figure 1). Central Vietnam was one of the areas that were subject to initial forestland allocation following Decree 163 in 1999. Table 1 presents some general information on the three provinces selected for this study, all of which are less densely populated compared to overall Vietnam, but have a higher forest cover.

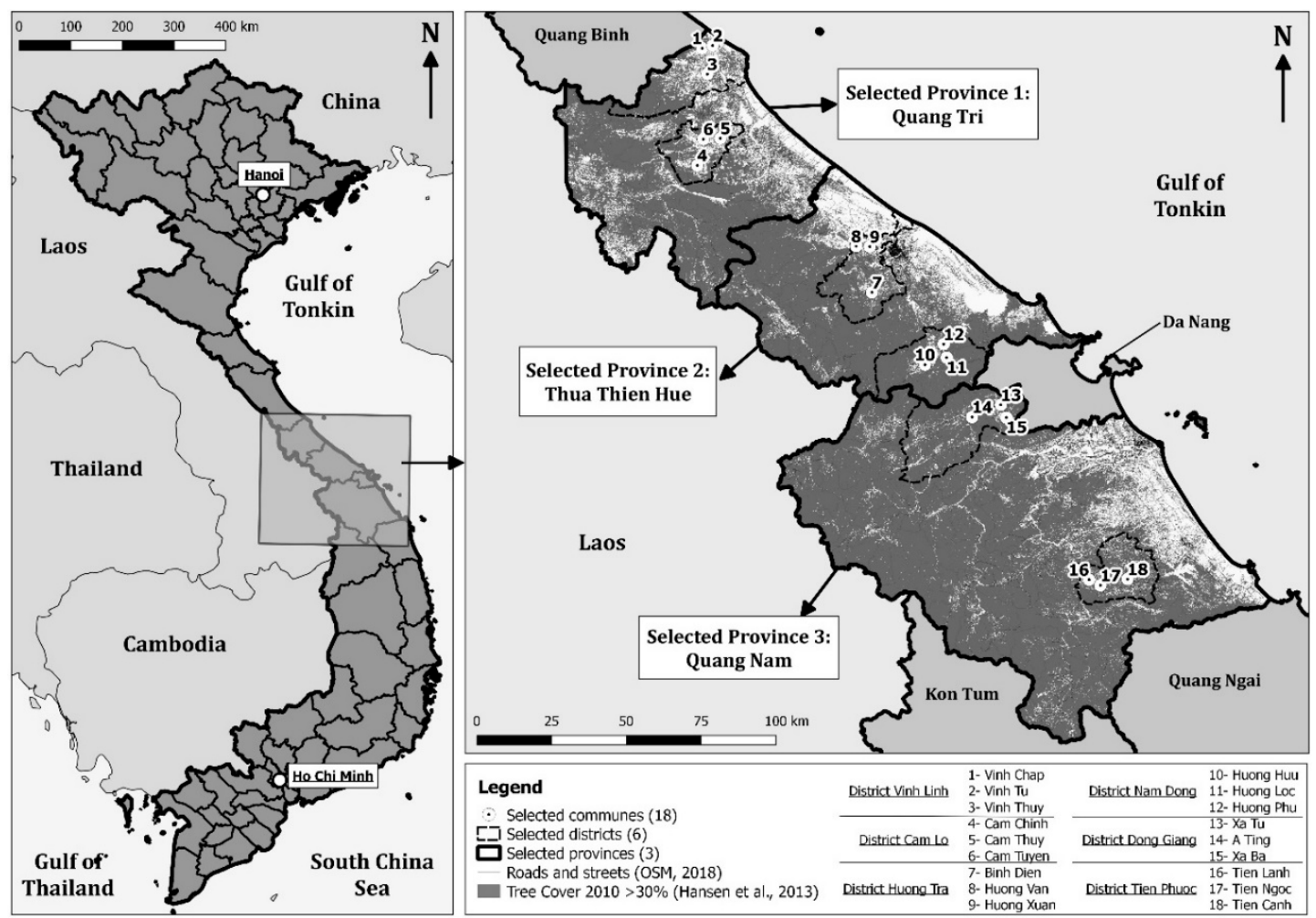

Figure 1. Location of the study communes.

Table 1. Population, total area, and forest cover in the study provinces in 2015.

\begin{tabular}{|c|c|c|c|c|c|c|}
\hline Province & $\begin{array}{l}\text { Population } \\
\text { (1000 Pers.) }\end{array}$ & $\begin{array}{c}\text { Population } \\
\text { Density } \\
\left(\text { person } / \mathrm{km}^{2}\right)\end{array}$ & $\begin{array}{c}\text { Area of Forest } \\
\text { (1000 ha) }\end{array}$ & $\begin{array}{l}\text { Natural Forest } \\
\text { (1000 ha) }\end{array}$ & $\begin{array}{l}\text { Planted Forest } \\
\text { (1000 ha) }\end{array}$ & $\begin{array}{c}\text { Forest cover } \\
(\%)\end{array}$ \\
\hline Quang Tri & 623.5 & 135 & 242.3 & 141.5 & 100.7 & 49.5 \\
\hline Thua Thien-Hue & 1149.8 & 235 & 298.6 & 203.1 & 95.5 & 56.9 \\
\hline Quang Nam & 1487.7 & 141 & 552.1 & 409.8 & 142.3 & 51.5 \\
\hline Vietnam total & 92695.1 & 280 & 14061.9 & 10175.5 & 3886.3 & 40.8 \\
\hline
\end{tabular}

Source: General Statistics Office of Vietnam (2018).

The 18 communes were selected according to two criteria. The first criterion was that the majority of households were involved in acacia plantations. Remoteness of communes to urban centers was the second criterion for sample selection, with infrastructure and distance to markets likely to play a strong role in explaining plantation owners' decisions regarding rotation periods of acacia. Communes were considered remote if their center was distant from the provincial center or a national highway, or if geographical conditions made access to them relatively difficult compared to other selected sites within 
each province. In total, 9 remotely located communes and 9 that were non-remote or substantially closer to national highways were selected (Table 2).

Table 2. Study site selection.

\begin{tabular}{|c|c|c|c|c|c|c|}
\hline & Commune & District & Province & $\begin{array}{l}\text { Distance to } \\
\text { Province } \\
\text { Center (km) }\end{array}$ & $\begin{array}{c}\text { Distance to } \\
\text { National } \\
\text { Highway (km) }\end{array}$ & $\begin{array}{c}\text { Remote } \\
\text { Area }\end{array}$ \\
\hline 1 & Vinh Chap & Vinh Linh & Quang Tri & 7.5 & 1.8 & \\
\hline 2 & Vinh Thuy & Vinh Linh & Quang Tri & 7 & 5.5 & \\
\hline 3 & Vinh $\mathrm{Tu}$ & Vinh Linh & Quang Tri & 7.2 & 5.4 & \\
\hline 4 & Cam Thuy & Cam Lo & Quang Tri & 9.8 & 5.5 & Yes \\
\hline 5 & Cam Tuyen & Cam Lo & Quang Tri & 23.6 & 12.4 & Yes \\
\hline 6 & Cam Chinh & Cam Lo & Quang Tri & 26 & 20.1 & Yes \\
\hline 7 & Huong Van & Huong Tra & Thue Thien Hue & 13 & 5.2 & \\
\hline 8 & Huong Xuan & Huong Tra & Thue Thien Hue & 11 & 0.5 & \\
\hline 9 & Binh Dien & Huong Tra & Thue Thien Hue & 28 & 10.5 & \\
\hline 10 & Huong Phu & Nam Dong & Thue Thien Hue & 43.2 & 19.8 & Yes \\
\hline 11 & Huong Loc & Nam Dong & Thue Thien Hue & 57.6 & 31.7 & Yes \\
\hline 12 & Huong Huu & Nam Dong & Thue Thien Hue & 58.3 & 34.2 & Yes \\
\hline 13 & Tien Lanh & Tien Phuoc & Quang Nam & 57 & 49.1 & \\
\hline 14 & Tien Canh & Tien Phuoc & Quang Nam & 31.3 & 28.7 & \\
\hline 15 & Tien Ngọc & Tien Phuoc & Quang Nam & 51.5 & 44.4 & \\
\hline 16 & Xa Tu & Dong Giang & Quang Nam & 103 & 44.6 & Yes \\
\hline 17 & $\mathrm{Xa} \mathrm{Ba}$ & Dong Giang & Quang Nam & 107 & 35.5 & Yes \\
\hline 18 & Xa Ating & Dong Giang & Quang Nam & 125 & 72.8 & Yes \\
\hline
\end{tabular}

Source: Distances are calculated based on Google Maps, 28 November 2018. www.google.com/maps.

For this study, in total 315 households, 105 for each province, were randomly selected out of the 18 communes based on the census information from commune leaders. However, the number of analyzed interviews was reduced to 306 because for 9 cases out of the 315 listed households either nobody was at home to answer the questionnaire or the data reported were evaluated as inconsistent. Structured questionnaires were used for conducting household interviews that covered information from households' socio-economic characteristics, tree plantation management and information on all other livelihood activities for the past 12 months from the time when this survey was conducted.

In order to gain a better understanding of plantation owners' perceptions and attitudes in relation to sawlog production from long rotation periods, focus group discussions (FGDs) were conducted in each of the selected communes. The purpose of the FGDs was to gain insights on smallholder incentives and disincentives related to sawlog production that could not be captured in the structured household questionnaires.

\subsection{Data Analysis}

The empirical model employed in this study was designed to estimate the impact of the farm and farmer characteristics, as well as the characteristics of the external environment on the adoption of long rotation periods for sawlog production. The choice of variables for the empirical analysis is based on the framework of Meijer et al. on the theory of innovation adoption [13]. The innovation in the current study refers to long rotation periods for the production of sawlogs by extending the rotation period and targeting a new output.

The probit model is used to estimate the probability of adopting long rotation periods, which is formulated as follows:

$$
\operatorname{Pr}(Y=1 \mid X)=G(z)=\int_{-\infty}^{X^{\prime} \beta} \phi(z) d Z=\Phi\left(X^{\prime} \beta\right)
$$


where the values of the function $G(z)$ range between 0 and $1, Y$ is the binary variable, equal to 1 if a household produces sawlogs from acacia plantations, or 0 otherwise; $\operatorname{Pr}$ denotes the probability that a farm household is involved in sawlog production from acacia plantations; $\Phi\left(X^{\prime} \beta\right)$ is the cumulative distribution function of the standard normal distribution; $X$ is the vector of explanatory variables; and $\phi(z)$ is the standard normal density function. The parameters of the $\beta$ vector are estimated using the maximum likelihood method. The empirical model estimates the underlying latent variable model:

$$
\begin{gathered}
Y^{*}=X \beta+e \\
Y=\left\{\begin{array}{l}
1, \text { if } Y^{*}>0 \\
0, \text { if } Y^{*}<0
\end{array}\right\}
\end{gathered}
$$

As the interpretation of the coefficient estimates from the model described in (2) are not intuitive, average marginal effects (AME) are estimated. Marginal effects indicate the average change in the probability to adopt long rotation periods when an explanatory variable increases by one unit for continuous variables, or for a discrete change from 0 to 1 for dummy variables. For a non-linear model like probit, this effect will differ between households. Therefore, the AME calculates the average of all individual effects included in the analysis.

Due to the low number of households in the group that produced sawlogs within the study sample of 306 randomly selected households, the binary regression model estimations might have an overfitting bias if too many predictors are included, because the number of events per predictor (EVP) is very small [14]. In order to avoid this bias, simple probit regressions were performed with just one predictor in each model, to check whether there is any statistically significant association of selected predictors with the probability to adopt long rotation periods for sawlog production. Bivariate relationships were tested between the different variables (farm, farmer and external environment characteristics) and the decision of the farm household to produce sawlogs from acacia plantations. All model estimations were performed in Stata 15.

\subsection{Definition of Variables}

The dependent variable used in the probit regression models is a binomial categorical variable, which takes the value of 1 if a household produces sawlogs from its acacia plantations and 0 if a household produces only woodchip timber.

Independent variables included in the probit models can be categorized into three groups: (1) household characteristics, (2) farm characteristics, and (3) the variables describing an external environment and income shocks. The definition of most of the independent variables is given directly in Tables 3-5, while a few variables that were calculated by authors require further clarification. These variables are land fragmentation index, total number of shocks, and the physical assets index.

Fragmentation of land into small plots is also likely to play a role in the decision-making of households on rotation periods of acacia. An indicator for land fragmentation is calculated using the Simpson's index [15]:

$$
S=1-\frac{\sum_{i=1}^{N} a_{i}^{2}}{\left(\sum_{i=1}^{N} a_{i}\right)^{2}}
$$

where $a_{i}$ is the size of plot $i$ in ha and $\mathrm{N}$ is the total number of plots owned by a household. The land fragmentation index ranges between 0 and 1, with values closer to 1 indicating more fragmentation.

Total number of income shocks over the past 12 months is a sum of different events that have caused significant additional expenditures to households or a shock to their incomes.

A physical asset index was calculated based on the information on ownership of durable assets, including cars, motorbikes, and TV sets. Relative weights have been assigned to each asset type based on their average prices and then summed up for each household. This index is a relative measure and equal to 1 for a household that had the largest asset endowment in the study sample. 
Table 3. Differences between forest owners who produce and who do not produce sawlogs: categorical variables.

\begin{tabular}{|c|c|c|c|c|}
\hline \multirow[b]{2}{*}{ Categorical Variables } & \multicolumn{3}{|c|}{ Proportion of Households, $\%$ to Total } & \multirow[b]{2}{*}{$\begin{array}{c}\text { Two-Sample test } \\
\text { of Proportions, } \\
p \text {-Value }\end{array}$} \\
\hline & $\begin{array}{c}\text { Produce } \\
\text { Sawlogs = yes } \\
n=19\end{array}$ & $\begin{array}{c}\text { Produce } \\
\text { Sawlogs = no } \\
n=287\end{array}$ & $\begin{array}{c}\text { All } \\
\text { Households } \\
n=306\end{array}$ & \\
\hline \multicolumn{5}{|l|}{ HOUSEHOLD } \\
\hline \multicolumn{5}{|l|}{ CHARACTERISTICS } \\
\hline Household head is female ( $1=$ yes $)$ & 0 & 7.7 & 7.2 & 0.21 \\
\hline Own the house on their own ( $1=$ yes $)$ & 94.7 & 97.9 & 97.7 & 0.37 \\
\hline $\begin{array}{l}\text { Household head had high education } \\
(1=\text { yes })\end{array}$ & 0 & 6.6 & 6.2 & 0.24 \\
\hline $\begin{array}{l}\text { Main occupation of household head is } \\
\text { in agriculture ( } 1=\text { yes) }\end{array}$ & 89.5 & 81.8 & 82.2 & 0.36 \\
\hline Kinh ethnicity $(1=$ yes $)$ & 94.7 & 78.1 & 79.1 & $0.08 *$ \\
\hline Co Tu ethnicity $(1=$ yes $)$ & 5.3 & 20.9 & 19.9 & $0.09 *$ \\
\hline Official title for the land ( $1=$ yes $)$ & 73.7 & 58.9 & 59.8 & 0.20 \\
\hline Livestock ownership $(1=$ yes $)$ & 89.5 & 83.9 & 84.2 & 0.48 \\
\hline Fish catching $(1=$ yes $)$ & 10.5 & 17.5 & 17.1 & 0.66 \\
\hline \multicolumn{5}{|l|}{ FARM CHARACTERISTICS } \\
\hline $\begin{array}{l}\text { Location in a remote commune } \\
(1=\text { yes })\end{array}$ & 26.3 & 46 & 44.8 & $0.09 *$ \\
\hline $\begin{array}{l}\text { Good road quality from the } \\
\text { homestead to the commune center } \\
\text { (1= yes) }\end{array}$ & 100 & 93.7 & 94.1 & 0.26 \\
\hline $\begin{array}{l}\text { Access to paved road from the acacia } \\
\text { plantation }(1=\text { yes })\end{array}$ & 57.9 & 27.9 & 29.7 & $0.01 * * *$ \\
\hline \multicolumn{5}{|l|}{$\begin{array}{l}\text { EXTERNAL ENVIRONMENT AND } \\
\text { INCOME SHOCKS }\end{array}$} \\
\hline $\begin{array}{l}\text { Credit request has been approved } \\
(1=\text { yes })^{\text {a }}\end{array}$ & 100 & 92.2 & 92.7 & 0.39 \\
\hline $\begin{array}{l}\text { Credit requested from the } \\
\text { government }{ }^{\text {a }}(1=\text { yes })\end{array}$ & 91.7 & 94.1 & 93.9 & 0.59 \\
\hline $\begin{array}{l}\text { Credit invested in crop production }{ }^{\text {a }} \\
(1=\text { yes })\end{array}$ & 33.3 & 32.5 & 32.6 & 0.61 \\
\hline $\begin{array}{l}\text { Credit invested in tree plantations }{ }^{a} \\
(1=\text { yes })\end{array}$ & 16.7 & 6.6 & 7.3 & 0.19 \\
\hline Serious crop failure $(1=$ yes $)$ & 52.6 & 43.6 & 44.1 & 0.44 \\
\hline $\begin{array}{l}\text { Serious illness of a family member } \\
(1=\text { yes })\end{array}$ & 5.3 & 21.3 & 20.3 & $0.09 *$ \\
\hline Death of family member $(1=$ yes $)$ & 0 & 1.7 & 1.6 & 0.56 \\
\hline Land loss $(1=$ yes $)$ & 5.3 & 2.4 & 2.6 & 0.45 \\
\hline Major livestock loss (1 = yes) & 0 & 8.4 & 7.8 & 0.19 \\
\hline Other major asset loss $(1=$ yes $)$ & 0 & 0.7 & 0.6 & 0.71 \\
\hline Lost wage employment ( 1 = yes) & 0 & 1.4 & 1.3 & 0.60 \\
\hline $\begin{array}{l}\text { Wedding or other costly events } \\
(1=\text { yes })\end{array}$ & 21.1 & 16.7 & 17 & 0.63 \\
\hline Drought $(1=$ yes $)$ & 5.3 & 17.1 & 16.3 & 0.18 \\
\hline Flood or too much rain $(1=$ yes $)$ & 42.1 & 38.7 & 38.9 & 0.77 \\
\hline Insufficient energy supply ( 1 = yes) & 0 & 0.7 & 0.7 & 0.72 \\
\hline $\begin{array}{l}\text { Delayed payments for farm output } \\
(1=\text { yes })\end{array}$ & 0 & 1.7 & 1.6 & 0.57 \\
\hline $\begin{array}{l}\text { Inability to sell own farm products } \\
(1=\text { yes })\end{array}$ & 5.9 & 5.6 & 5.6 & 0.96 \\
\hline
\end{tabular}

Source: Authors' estimations based on the data from the household survey. ${ }^{a}$ includes only households that have applied for a credit: 176 households that did not produce sawlogs, and 12 households that produce sawlogs. * **, and ${ }^{* * *}$ significant at $0.1,0.01$ and 0.001 confidence levels respectively. 
Table 4. Differences between forest owners who produce and who do not produce sawlogs: continuous variables.

\begin{tabular}{|c|c|c|c|c|c|}
\hline \multirow{2}{*}{ Variables } & \multicolumn{2}{|c|}{ Produce Sawlogs $=$ No } & \multicolumn{2}{|c|}{ Produce Sawlogs $=$ Yes } & \multirow[t]{2}{*}{$\begin{array}{c}\text { Mean } \\
\text { Difference }\end{array}$} \\
\hline & Mean & Std. Dev. & Mean & Std. Dev. & \\
\hline & 1 & 2 & 3 & 4 & $(1)-(3)$ \\
\hline \multicolumn{6}{|l|}{ HOUSEHOLD CHARACTERISTICS } \\
\hline Age of the household head & 50.9 & 11.4 & 49.6 & 9.9 & 1.3 \\
\hline Household size & 4.3 & 1.3 & 4.1 & 1.5 & 0.2 \\
\hline Livestock assets, TLU & 1.5 & 2.4 & 1.4 & 1.3 & 0.05 \\
\hline Physical assets index & 0.4 & 0.2 & 0.4 & 0.2 & -0.03 \\
\hline Remittances, thous. VND & 1700 & 9315 & 474 & 1504 & $1227 *$ \\
\hline Annual income from self-employment, thous. VND & 11007 & 27306 & 9811 & 24688 & 1197 \\
\hline $\begin{array}{l}\text { Value of products collected from primary public } \\
\text { forests, thous. VND }\end{array}$ & 88 & 454 & 4 & 16 & $84^{* * *}$ \\
\hline Income from fishing activities, thous. VND & 1476 & 8367 & 1020 & 2393 & 456 \\
\hline Experience with acacia, years & 11.9 & 6.3 & 11.5 & 6.5 & 0.42 \\
\hline \multicolumn{6}{|l|}{ FARM CHARACTERISTICS } \\
\hline Total land size, ha & 4.2 & 4.2 & 7.6 & 7.1 & $-3.43 * *$ \\
\hline Land under acacia, ha & 3.4 & 3.6 & 6.7 & 6.2 & $-3.28 * *$ \\
\hline Total number of plots & 4.2 & 1.7 & 4.6 & 2.1 & -0.43 \\
\hline Land fragmentation index & 0.51 & 0.22 & 0.52 & 0.25 & -0.01 \\
\hline \multicolumn{6}{|l|}{$\begin{array}{l}\text { EXTERNAL ENVIRONMENT AND INCOME } \\
\text { SHOCKS }\end{array}$} \\
\hline $\begin{array}{l}\text { Total number of income shocks over the past } \\
12 \text { months }\end{array}$ & 2.31 & 1.9 & 2.05 & 1.61 & 0.26 \\
\hline Distance from the house to the commune center, $\mathrm{km}$ & 2.2 & 2.1 & 2.6 & 1.4 & -0.42 \\
\hline Distance from the patch to the nearest road, $\mathrm{m}$ & 718 & 1071 & 437 & 542 & $280.67^{* *}$ \\
\hline
\end{tabular}

Source: Authors' estimations based on the data from the household survey. ${ }^{*}, * *$, and ${ }^{* * *}$ significant at $0.1,0.01$ and 0.001 confidence levels respectively.

Table 5. Summary of simple probit regressions.

\begin{tabular}{|c|c|c|c|c|c|}
\hline \multirow[t]{2}{*}{ Variable } & \multicolumn{2}{|c|}{ Parameter Estimates } & \multicolumn{2}{|c|}{$\begin{array}{l}\text { Average Marginal } \\
\text { Effects }\end{array}$} & \multirow[t]{2}{*}{ LR $\operatorname{chi}^{2}(1)$} \\
\hline & Coefficient & Std. Error & $\mathrm{dy} / \mathrm{dx}$ & Std. Error & \\
\hline \multicolumn{6}{|l|}{ HOUSEHOLD CHARACTERISTICS } \\
\hline Age of the household head & -0.005 & 0.01 & -0.0006 & 0.001 & 0.23 \\
\hline Household size & -0.055 & 0.086 & -0.007 & 0.01 & 0,4 \\
\hline Kinh ethnicity ( 1 = yes $)$ & $0.71 *$ & 0.413 & $0.059 * *$ & 0.023 & $3.93^{* *}$ \\
\hline Livestock assets, TLU & -0.005 & 0.054 & -0.0007 & 0.066 & 0.01 \\
\hline Remittances, thous. VND & -0.0001 & 0 & 0 & 0 & 0.45 \\
\hline $\begin{array}{l}\text { Annual income from self-employment, } \\
\text { thous. VND }\end{array}$ & -0.0001 & 0 & 0 & 0 & 0.85 \\
\hline Household assets index, \% & 0.508 & 0.675 & 0.062 & 0.081 & 0.453 \\
\hline Household head had high education $(1=$ yes $)$ & -0.013 & 0.078 & -0.002 & 0.009 & 0.03 \\
\hline Total fish revenue, thous. VND & 0 & 0 & 0 & 0 & 0.08 \\
\hline \multicolumn{6}{|l|}{ FARM CHARACTERISTICS } \\
\hline Land under acacia, ha & $0.067 * *$ & 0.023 & $0.007^{* *}$ & 0.003 & $8.3^{* *}$ \\
\hline Land fragmentation index, $\%$ & 0,066 & 0.498 & 0.008 & 0.061 & 0.02 \\
\hline Official title for the land ( 1 = yes) & 0.314 & 0.246 & 0.036 & 0.027 & 1.71 \\
\hline Distance from a patch to the nearest road, $\mathrm{m}$ & -0.0002 & 0.0002 & 0 & 0 & 1.74 \\
\hline $\begin{array}{l}\text { Access to paved road from the acacia } \\
\text { plantation }(1=\text { yes })\end{array}$ & $0.613 * *$ & 0.233 & $0.084^{* *}$ & 0.037 & $6.95^{* *}$ \\
\hline \multicolumn{6}{|l|}{ EXTERNAL ENVIRONMENT AND } \\
\hline \multicolumn{6}{|l|}{ INCOME SHOCKS } \\
\hline Location in a remote commune ( $1=$ yes $)$ & $-0.407^{*}$ & 0.244 & $-0.046^{*}$ & $0.027 *$ & $2.93 *$ \\
\hline Total number of shocks & -0.037 & 0.063 & -0.005 & 0.008 & 0.36 \\
\hline Serious illness of a family member $(1=$ yes $)$ & $-0.693 *$ & 0.414 & $-0.058^{* *}$ & 0.023 & $3.68 *$ \\
\hline Drought $(1=$ yes $)$ & -0.580 & 0.426 & $-0.050 * *$ & 0.025 & 2.32 \\
\hline Flood or too much rain $(1=$ yes $)$ & 0.068 & 0.229 & 0.008 & 0.028 & 0.09 \\
\hline
\end{tabular}

Source: Authors' estimations based on the data from the household survey. ${ }^{*}{ }^{* *}$, and ${ }^{* * *}$ significant at $0.1,0.01$ and 0.001 confidence levels respectively. Coefficient estimates for the constant term are not reported. TLU refers to tropical livestock units. 


\section{Results}

\subsection{Differences Between Forest Owners Who Produce and Who Do Not Produce Sawlogs}

Only 19 (6.2\%) out of 306 surveyed households produced sawlogs. Farmer, farm and external environment characteristics for the surveyed households are summarized in Tables 3 and 4 . In order to receive a first glance on potential differences between the group of farmers that produce sawlogs and those who do not, proportions of positive responses for categorical variables for both groups were compared using the two-sample test of proportions (Table 3 ) and $t$ tests were conducted for mean differences for continuous variables (Table 4).

The majority of households were of Kinh ethnicity $(79.1 \%)$, followed by Co Tu (19.9\%), with the share of Kinh being much larger (94.7\%) in the group that produce sawlogs (Table 3). A larger share of households in the group that produce sawlogs had access to paved roads both from their homestead and from their acacia plantations (Table 3). As revealed during discussions with farmers, the distance to the nearest road and access to paved roads from the acacia plantation can play an important role in determining prices for acacia.

Tenure security is likely to have an important effect when explaining long-term decisions of farmers regarding rotation periods. In the study region, $60 \%$ of all households had a permanent land title for at least one of their acacia plots. This figure was $74 \%$ among the households that produced sawlogs (Table 3). The majority of households sold all timber from acacia plantations to intermediaries $(87.5 \%)$, the remaining $12.5 \%$ sold their produce directly at a market located in the same district or municipality. None of the households reported a direct contact to timber processing companies. In most cases, intermediaries purchased the whole timber from a given patch of land and carried out the related costs of harvesting and transporting.

The differences become more evident when farm characteristics are examined. Land size available for the farm household in total, as well as the land under acacia plantations are significantly larger for the group of households that produce sawlogs (Table 4). This implies that the smallness of land could be one of the important factors that prevents farm households from participation in sawlog production. Both groups had on average 11 years of experience with acacia plantations and had their land dispersed into more than four plots. For both groups of farm households, the land fragmentation index is relatively high, at more than 0.5 , but there is no significant difference between the two groups (Table 4). Table 4 provides information on how often an individual income shock was experienced by both groups of farm households. A larger proportion of households within the group that did not produce sawlogs experienced income shocks related to the illness of a family member, drought, and livestock loss. A higher occurrence of droughts could be an important factor that affects households' decisions on overall farm investments and rotation periods for acacia.

Compared to households that were not involved in sawlog production, producers of sawlogs collected smaller volumes of wood and non-wood forest products from primary public forests. However, for both groups, the total value of forest products collected seems negligible, e.g., for households that did not produce sawlogs this value comprised only 88 thousand VND (3.8 US\$) per year. Moreover, only a small share of surveyed households (17.6\%) collected any forest products from primary public forests. No significant differences were observed for income from fishing activities or from self-employment, nor for livestock and household assets (Table 4).

\subsection{Plantation Owners' Perceptions and Attitudes on Sawlog Production}

Figure 2 summarizes plantation owners' answers on potential factors that would constrain them from increasing the acacia rotation length for the production of sawlogs from that required for woodchip. In almost all focus groups, forest owners were concerned about increased losses from natural disasters, such as typhoons. The losses were expected to increase due to longer waiting times until harvest. Cash shortages related to long rotation periods were mentioned in 16 out of 18 communes that were included in our survey. Forest owners indicated that 7-10 years of waiting for sawlog production 
would be too long, because it would limit availability of cash for everyday family expenses. Moreover, the longer waiting time for returns from sawlogs could create difficulties in paying off interests on debts. Farmers from several communes reported limited access to long-term credit that could help them to switch to the production of sawlogs.

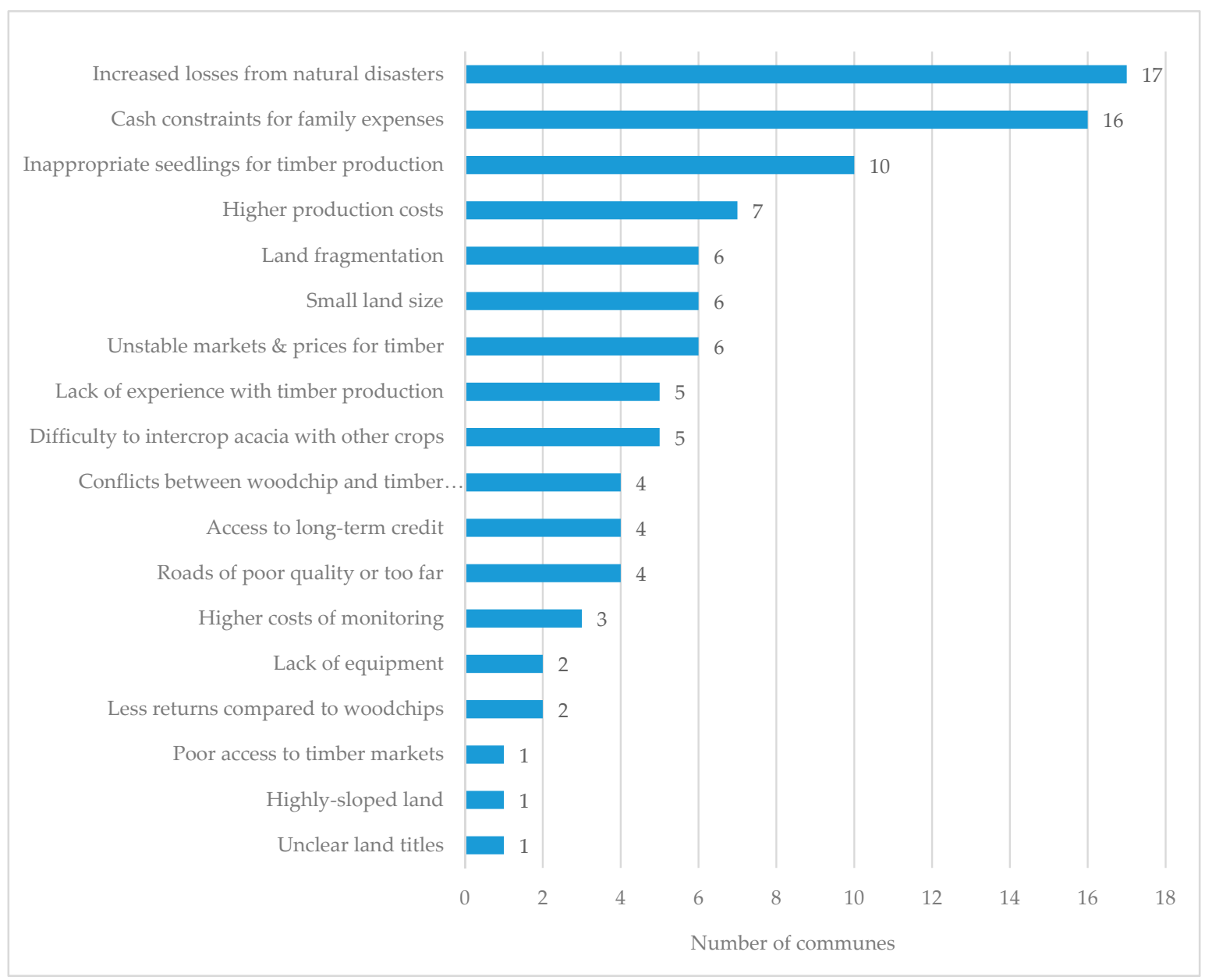

Figure 2. Potential disincentives to produce sawlogs as indicated by acacia plantation owners. Source: Data from focus group discussions.

Focus groups from more than half of the communes claimed that the existing acacia varieties are of low quality and are not suitable for increasing the rotation length in order to produce timber for sawlogs. Plantation owners expected that the currently provided seedlings would produce easily breakable soft wood.

Long rotation cycles can imply larger transportation costs for the harvested wood. In some cases, a plantation owner had to cut a temporary road through the tree plantation of a neighboring farmer for transporting their timber. For instance, in a remote commune in the Quang Nam province, these costs would be 50 thousand VND (US\$2.14) per tree if the removed trees were 3-4 years old.

Costs of monitoring the forest plantation, e.g., to protect from theft, would be larger due to longer waiting times. In some communes, plantation owners pointed out that the land area under their ownership would be insufficient and too fragmented for the production of sawlogs. Some also indicated that the smallness of plantation size impedes establishment of a safe belt for the whole plot against strong wind, fire, livestock and other risks.

According to plantation owners' reports during the FGDs, the market and the network of intermediaries are well established for woodchips, but not for sawlogs. In addition, plantation owners were concerned about unstable timber prices. 
A further potential disincentive to switch to long rotation periods, as indicated by farmers, could be that long rotation periods allow for less often intercropping. As reported in some focus groups, during the first year of the rotation, acacia would be intercropped with crops such as rice, cassava, sweet potatoes, and other vegetables. Therefore, a short rotation period would allow an intercropping every $4-5$ years, whereas with a long rotation cycle, such intercropping would be possible only every 7-10 years.

Finally, producing two different outputs with differing rotation periods could create a conflict between producers of woodchip and producers of sawlogs. Some farmers expressed concerns about increased fire risks, if neighboring plantations produce two different outputs, because a common practice after harvesting involves burning the field. Some of the themes were brought out by focus group discussions more often than others, particularly the risk of natural disasters, cash shortages for everyday expenses, inadequate seedling materials, higher production costs, and small and fragmented land holdings. In two communes, plantation owners' focus groups indicated that production of sawlogs would be less beneficial than the production of woodchips. One-third of the focus groups also reported that there is a lack of experience in plantation management for sawlog production.

\subsection{Results of the Regression Analysis}

Table 5 reports the results of the simple probit regression models. The Likelihood Ratio (LR) Chi-Square test-that the regression coefficient of an explanatory variable is not equal to zero-is reported for each regression model. The number in the parentheses indicates the degrees of freedom of the Chi-Square distribution test, which is 1 for a simple regression. Only 6 out of 19 coefficients are statistically significant at the $10 \%$ confidence level. Statistically significant bivariate relationships with the decision to adopt long rotation periods were observed for land size under acacia, Kinh ethnicity, location in a remote commune, access to paved road from acacia plantations, and two income shocks (drought and serious illness of a family member). The size of land used for tree plantations seems to be one of the important predictors of the probability to produce of sawlogs. The larger the land size, the more likely it is that the household produces sawlogs.

Belonging to the Kinh ethnicity was also found to be positively associated with the probability of having extended rotation periods and producing sawlogs from acacia plantations. Ethnicity is likely to be linked to other factors, particularly to location in a remote community and the average land size available for farm households. People from the Kinh ethnicity have a larger land size, while ethnic minorities like Co Tu are likely to live in comparatively remote locations and have smaller land size for acacia plantations. Location in a remote commune was another important factor influencing the probability of producing sawlogs by smallholder farm households.

Regression results further indicate that income shocks, such as drought and a serious illness of a family member are negatively associated with the production of sawlogs, and significantly reduce the probability of adopting long rotations.

In order to avoid the overfitting bias due to the small sample size of sawlog producers, a multivariate probit model with more than one independent variables could not be estimated. This implies that the results presented in Table 5 should be interpreted as the relationship of the included variables with the decision to adopt sawlog production, when other explanatory variables are not controlled for.

\section{Discussion}

Based on the focus group discussions and regression results, factors that potentially constrain small-scale plantation owners from production of sawlogs can be grouped into four themes: (1) small and fragmented land holdings, (2) high risks related to natural disasters and other biotic and abiotic hazards, (3) high production and monitoring costs, and (4) lack of knowledge and experience in plantation management. 


\subsection{Small and Fragmented Land Holdings}

Acacia plantations are the main livelihood activity for small-scale forest owners in the study area and many families cannot afford longer return periods for their investments associated with sawlog production. FGDs showed that extending the rotation period would cause cash shortages for everyday family expenses. Another major concern expressed during the FGDs was the smallness and fragmentation of land holdings. The land size averaged 4.2 ha for households that did not produce sawlogs, which is $93.8 \%$ of all interviewed households. In contrast, the mean land size for those who adopted sawlog production averaged 7.6 ha. These land holdings are divided on average into four plots. That land size leads to an increased ability to adopt long rotation periods is confirmed by regression analysis results.

A policy that intends to promote sawlog production among smallholders needs to address the issue of liquidity constraints and the small size of land holdings. One of the measures could be the introduction of contracts with timber companies, through the so called "out-grower systems". Establishing direct contracts with timber processing companies could increase the added value from acacia output for farm households in contrast to the current practice of selling timber to intermediaries prior to harvest. Moreover, establishment of out-grower schemes can ensure a guaranteed market, reduce the risks to a small plantation owner, and potentially provide financial support depending on the terms of the contract [16].

The establishment of cooperatives could be another measure to tackle the issues related to the smallness of farm size. Some donor projects promoted forest owner associations (FOAs) or so called forest farmer groups (FFG), but the uptake of these has so far been slow, with most households preferring to operate individually [17]. The Decision 2905/QD-BNV by the Vietnamese Government from August 22, 2016 states that forest owner associations are to be established throughout Vietnam, as a voluntary setting of plantation owners in order to support its members in forest management, to provide information and trainings. It is still unclear whether the establishment of forest owner associations will be sustained. More research is needed to understand the forest owners' needs with regards to such an organization. Operating in a group could help plantation owners to gain increased bargaining power in terms of purchasing inputs, as well as marketing their products.

\subsection{High Risks Related to Natural Disasters and Other Abiotic and Biotic Hazards}

Increasing the rotation periods for acacia plantations combined with thinning activities necessary for the production of sawlogs increases the risk of storm damage, especially in central Vietnam [12]. This part of Vietnam is frequently haunted by devastating typhoons, which can destroy stands in a few hours and lead to decreased prices for sawn timber. Soil erosion caused by high-intensity rainfall during the typhoon season can reduce stand productivity especially in central Vietnam, where thousands of plantation owners grow acacia on eroded soils [12].

During focus group discussions, plantation owners from many communes expressed concerns related to high risks of natural disasters, and particularly floods and storms. It has been argued in the literature that the high (perceived or real) risk of storms could be an important barrier that discourages small-scale forest owners from the long-term investments [11]. Small-scale plantation owners perceive risks of storm damage to be lower, if they harvest their trees after a short rotation [17].

Major biotic hazards for acacia plantations in Vietnam include heart rot diseases (especially relevant for sawlog production), pink disease caused by the fungus Erythricium salmonicolor that affects A. mangium and acacia hybrid, and leaf blight diseases [18].

Thus, promotion of longer rotation periods requires that the concerns of plantation owners related to various natural hazards and other uncertainties are addressed via the introduction of insurance schemes or other risk management measures, as well as adequate training and support to deal with the acacia diseases. 


\subsection{High Production and Monitoring Costs}

Due to the smallness of scale, transaction costs of plantation owners in relation to long rotation periods for the production of sawlogs can be very high. The FGD findings reveal that plantation owners expected switching to long rotations would require additional investments, in terms of better seed, higher equipment and machinery cost, as well as higher cost of monitoring for longer periods of time. Plantation owners in remote communes and with poor access to adequate quality roads are even less likely to adopt long rotations as indicated by the regression analysis results, probably because larger distance to markets and transport costs add to already high transaction costs related to long rotation periods for small-scale plantation owners.

FGD findings further showed that long rotation periods would also reduce the possibility of intercropping which can be repeated more often in short rotation systems. Future studies that compare returns to short and long rotation periods should incorporate this aspect. Otherwise, an important source of returns from investment into short rotation systems would be ignored and thus would not reflect the real trade-offs between the two rotation systems.

Production of sawlogs through long rotation periods might require specialized heavy machinery for harvesting and transportation [11], that is likely to be too costly for an individual forest owner due to the smallness of land holdings. An establishment of FOAs could help to reduce production costs via joint procurement of inputs or perhaps via sharing the costs of machinery, while monitoring tasks could be organized together with the other FOA members.

\subsection{Lack of Knowledge and Experience in Plantation Management}

As indicated by plantation owners during the FGDs, one of the potential disincentives to adopt long rotation periods is the lack of experience with plantation management for sawlog production. This outlines the importance of training that could be provided by extension services. However, due to the interlinkages between the various constraints of small-scale plantation owners with regards to long rotation periods, none of the measures will be successful if implemented alone. Adequate trainings seem necessary to support the plantation owners with the relevant information on silvicultural techniques. However, if the high risks and transaction costs related to the smallness of their holdings are not addressed, the adoption of long rotation periods is likely to remain low.

\section{Conclusions}

Low adoption of long rotations by smallholders, as revealed in this study, is associated with small and fragmented land holdings, high risks related to natural disasters, high production and monitoring costs, and a lack of knowledge and experience in plantation management. Potential policy approaches that seek to promote the adoption of long rotations by small-scale acacia growers should include a package of measures that simultaneously address the constraints of smallholders and the number of risks that they face, while ensuring that adoption of long rotation periods contributes to improved welfare of rural households in Vietnam. Future economic evaluations of farmers' decision-making should incorporate various risks that smallholders face in order to have a full picture of internal and external factors that influence their decision on sawlog production. One of the limitations of this study is that the number of households that produced sawlogs included in the survey is very small which is related to the general low adoption of the practice in the region, but also means that the regression results should be interpreted with some caution. For instance, some of the important differences between the farmers that produce sawlogs and those who do not could become visible only once a larger number of sawlog producers is included in the study. Nevertheless, the evidence reported in this paper provides useful findings about the situation of smallholders and important factors that constrain farmers from the production of sawlogs. 
Author Contributions: Conceptualization, E.Z., J.-M.S., S.Z., M.D., and S.G.; data collection, L.T.H.S. and E.Z.; formal analysis, E.Z., L.T.H.S.; funding acquisition, S.G., S.Z., and M.D.; writing—original draft, E.Z. and J.-M.S., writing-editing and review, all.

Funding: This research was funded by the German Federal Ministry of Food and Agriculture (BMEL) by decision of the German Bundestag, grant number W-VNM 14-01.

Acknowledgments: This study is part of the multi-stakeholder project "Contribution to close-to-nature private (small-scale) forest management and support to the FLEGT/VPA process in Vietnam" funded by the German Federal Ministry of Food and Agriculture (BMEL) by decision of the German Bundestag through GFA and implemented jointly by WWF Germany, WWF Vietnam, HessenForst, and the Thuenen Institute of International Forestry and Forest Economics. We would like to thank three anonymous reviewers for their valuable comments that helped to improve this manuscript. We also would like to thank Ruben Ferrer for his support with GIS data.

Conflicts of Interest: The authors declare no conflict of interest.

\section{References}

1. FAO. Global Forest Resources Assessment, Country Report: Vietnam; Food and Agriculture Organization of the United Nations: Rome, Italy, 2015.

2. GSO. Statistical Data on Agriculture, Forestry and Fishery; General Statistics Office of Vietnam: Hanoi, Vietnam, 2018.

3. Meyfroidt, P.; Lambin, E.F. The causes of the reforestation in Vietnam. Land Use Policy 2008, 25, $182-197$. [CrossRef]

4. McElwee, P. Reforesting "bare hills" in Vietnam: Social and environmental consequences of the 5 million hectare reforestation program. Ambio J. Hum. Environ. 2009, 38, 325-333. [CrossRef] [PubMed]

5. ITTO. Biennial Review and Assessment of the World Timber Situation 2015-2016; International Tropical Timber Organization: Yokohama, Kanagawa Prefecture, Japan, 2017.

6. Orwa, C.; Mutua, A.; Kindt, R.; Jamnadass, R.; Simons, A. Agroforestree Database: A Tree Reference and Selection Guide Version 4.0; World Agroforestry Centre: Nairobi, Kenya, 2009.

7. Nambiar, E.K.S.; Harwood, C.E.; Kien, N.D. Acacia plantations in Vietnam: Research and knowledge application to secure a sustainable future. South. For. 2015, 77, 1-10. [CrossRef]

8. Kien, N.D.; Thinh, H.H.; Kha, L.D.; Nghia, N.H.; Hai, P.H.; Hung, T.V. Acacia as a national resource of Vietnam: Sustaining the future of acacia plantation forestry. In Proceedings of the IUFRO Acacia 2014 Conference "Sustaining the Future of Acacia Plantation Forestry" Working Party WP 2.08.07 on Acacia Genetics and Silviculture, Hue, Vietnam, 18-21 March 2014.

9. Harwood, C. Strengthening the tropical acacia plantation value chain: The role of research. J. Trop. Sci. 2011, 23, 1-3.

10. MARD. EU Agreements a Chance to Eradicate Illegal Timber Trade. Available online: https://www.mard.gov.vn/ en/Pages/eu-agreements-a-chance-to-eradicate-illegal-timber-trade-1068.aspx (accessed on 5 December 2018).

11. Maraseni, T.N.; Son, H.L.; Cockfield, G.; Duy, H.V.; Nghia, T.D. Comparing the financial returns from acacia plantations with different plantation densities and rotation ages in Vietnam. For. Policy Econ. 2017, 83, 80-87. [CrossRef]

12. Harwood, C.E.; Nambiar, E.K.S.; Dinh, P.X.; Toan, L.X.; Quang, L.T. Managing wood production from small grower acacia hybrid plantations on eroded soils in central Vietnam. Aust. For. 2017, 80, 286-293. [CrossRef]

13. Meijer, S.S.; Catacutan, D.; Ajayi, O.C.; Sileshi, G.W.; Nieuwenhuis, M. The role of knowledge, attitudes and perceptions in the uptake of agricultural and agroforestry innovations among smallholder farmers in sub-Saharan Africa. Int. J. Agric. Sustain. 2015, 13, 40-54. [CrossRef]

14. Babyak, M.A. What you see may not be what you get: A brief, nontechnical introduction to overfitting in regression-type models. Psychosom. Med. 2004, 66, 411-421. [PubMed]

15. Ciaian, P.; Guri, F.; Rajcaniova, M.; Drabik, D.; Gomez y Paloma, S. Land fragmentation and production diversification: A case study from rural Albania. Land Use Policy 2018, 76, 589-599. [CrossRef]

16. Desmond, H.; Race, D. Global Survey and Analytical Framework for Forestry Out-Grower Arrangements; Final Report Prepared for the Food and Agriculture Organization of the United Nations; Food and Agriculture Organization of the United Nations: Rome, Italy, 2000. 
17. World Bank. Vietnam Forest Sector Development Project; Project Performance Assessment Report No. 123895; The World Bank: Washington, DC, USA, 2018.

18. Nambiar, E.K.S.; Harwood, C.E. Productivity of acacia and eucalypt plantations in Southeast Asia. 1. Bio-physical determinants of production: Opportunities and challenges. Int. For. Rev. 2014, 16, 225-248. [CrossRef] 